\title{
STUDI KESALAHAN PEMAKAIAN EJAAN DAN STRUKTUR KARANGAN EKSPLANASI SISWA KELAS VIII SMP NEGERI 1 BANYUDONO
}

\author{
Dani Dwi Susanti ${ }^{1}$, Andayani², Edy Suryanto $^{3}$ \\ Universitas Sebelas Maret \\ Email: dani.dwi0312@gmail.com¹,bu_anda09@yahoo.co.id ${ }^{2}$, \\ edy.kelikuns@gmail.com³
}

\begin{abstract}
Abstrak: Penelitian ini merupakan studi kasus menggunakan metode kualitatif yang bersifat deskriptif dengan subjek penelitian 21 karangan eksplanasi karya siswa kelas VIII. Hasil penelitian menunjukan bahwa (1) terdapat 447 temuan kesalahan penggunaan ejaan, meliputi penulisan unsur serapan $(0,06 \%)$, penulisan kata $(8,27 \%)$, pemakaian tanda baca $(18,34 \%)$, dan pemakaian huruf $(72,70 \%)$ dengan didominasi kesalahan huruf kapital $(70,69 \%)$ berupa temuan pola kesalahan pemakaian huruf kapital; (2) terdapat tujuh karangan yang memiliki kesalahan struktur, meliputi struktur karangan tidak runtut, jenis karangan yang rancu serta adanya fakta bahwa struktur karangan tidak lengkap mendominasi pada temuan kesalahan dan menjadi salah satu pemicu adanya kesalahan yang lain; (3) faktor penyebab terjadinya kesalahan tersebut adalah kurang latihan menulis, kurang teliti, kurangnya pemahaman siswa, kebiasaan berbahasa siswa, serta kurangnya minat siswa dalam mengikuti pelajaran yang merupakan faktor dominan karena memperparah faktor-faktor yang lain; (4) tindakan preventif, siswa memilih belajar menggunakan ejaan dengan benar dan menulis teks eksplanasi; guru melakukan koreksi secara langsung, menekankan punishment, penggunaan pedoman ejaan dan ciri khas teks kepada siswa; pihak sekolah, terutama kepala sekolah, melakukan supervisi dan menggiatkan literasi sekolah, serta (5) baik siswa, guru, dan kepala sekolah memberi saran guna menangani kesalahan tersebut, yakni penggunaan media pembelajaran yang menyenangkan dan mewujudkan suasana pembelajaran yang nyaman, pembiasaan menggunakan PUEBI, serta sinergi dari pihak-pihak terkait.
\end{abstract}

Kata kunci: kesalahan ejaan, kesalalahan struktur teks, teks eksplanasi

\section{ANALYSIS OF SPELLING ERRORS AND EXPLANATION STRUCTURE OF JUNIOR HIGH SCHOOL STUDENTS EXPLANATION}

\begin{abstract}
This research is a case study using descriptive qualitative methods with 21 research subjects explanatory essays written by class VIII students. The results showed that (1) there were 447 findings of spelling errors, including the writing of absorption elements $(0.06 \%)$, word writing $(8.27 \%)$, use of punctuation marks $(18.34 \%)$, and use of letters $(72,70 \%)$ dominated by capital letters errors $(70.69 \%)$ in the form of findings of patterns of capital letters errors; (2) there are seven articles that have structural errors, including the structure of the composition which is not coherent, the ambiguous type of the article, and the fact that incomplete of the structure dominates the findings of structural errors and becomes one of the triggers for other errors; (3) the factors causing the error are lack of writing practice, less thoroughness, lack of understanding of students, students' language habits, and lack of student interest in following lessons which are the dominant factors because it exacerbates other factors; (4) preventive action, students choose to learn to use spelling correctly and write explanatory text; the teacher makes direct corrections, emphasizes punishment, the use of spelling guidelines and text characteristics to students; the
\end{abstract}

BASASTRA Jurnal Bahasa, Sastra, dan Pengajarannya

Volume 8 Nomor 2, Oktober 2020, P-ISSN 2302-6405, E-ISSN 2714-9765 
school, especially the principal, supervises and activates school literacy, and (5) both students, teachers and school principals provide advice to deal with these mistakes, namely the use of fun learning media and creating a comfortable learning atmosphere, habituation to using PUEBI, as well as synergy from related parties.

Keywords: spelling errors, text structure errors, explanation text

\section{PENDAHULUAN}

Fungsi bahasa Indonesia sebagai pengantar resmi di lembaga pendidikan menuntut penggunaan yang baik dan benar dalam pembelajaran sesuai pedoman yang telah ditetapkan. Hal ini tidak hanya dilakukan oleh guru, melainkan juga diajarkan kepada siswa. Keterampilan berbicara, menyimak, membaca dan menulis yang merupakan empat keterampilan berbahasa termuat dalam pem-belajaran bahasa Indonesia di semua jenjang pendidikan, salah satunya adalah keterampilan menulis karangan. Ke-terampilan menulis adalah kegiatan me-nyampaikan ide, gagasan, informasi, atau perasaan dalam bentuk lambang-lambang berupa tulisan secara terampil yang dapat dipahami dan bermanfaat bagi pembaca (Putri \& Elvina, 2019: 5). Nasrillah, Kosasih \& Kurniawan (2019) menuliskan sebuah artikel yang dilatarbelakangi fakta bahwa teks eksplanasi merupakan jenis teks baru dalam mata pelajaran bahasa Indonesia sejak berlakunya kurikulum 2013.

Penting untuk menyusun sebuah teks eksplanasi dengan memerhatikan pemakaian bahasa dan struktur karangan. Penulis harus berusaha agar bahasa Indonesia yang digunakan menunjukkan sifat yang cendekia, lugas dan jelas, serta menghindari kalimat fragmentaris dalam sebuah karangan ilmiah dengan cara menampakkan pilihan kata, pengembangan kalimat, pengembangan paragraf, kecermatan menggunakan ejaan, tanda baca, dan aspek lainnya dalam karangannya (Nurdjan, Firman \& Mirnawati, 2018). Selain itu, struktur teks eksplanasi diawali dengan pernyataan umum, kemudian penjelasan sebab-akibat yang merupakan penjelasan detail tentang topik yang dipaparkan dibagian pernyataan umum, ditutup dengan bagian interpretasi yang berisi inti sari topik yang dibahas (Nurdiana, Meisawati \& Mudikawaty, 2018).

Berdasarkan hasil pengamatan peneliti terhadap karangan eksplanasi siswa kelas VIII di SMPN 1 Banyudono, didapati kesalahankesalahan struktur teks maupun penggunaan ejaan. Ketika guru bahasa menunjukan kesalahan yang dialami peserta didik, guru harus tahu bentukbentuk kesalahan yang ada, penyebab kesalahannya, kaidah bahasa yang dilanggarnya, dan dapat menunjukkan bentuk yang benar, tepat, dan efektif (Markhamah \& Sabardila, 2014). Oleh karena itu, faktor penyebab dan apa solusi untuk mengatasi kesalahan

BASASTRA Jurnal Bahasa, Sastra, dan Pengajarannya

Volume 8 Nomor 2, Oktober 2020, P-ISSN 2302-6405, E-ISSN 2714-9765 
tersebut baik dari sudut pandang siswa maupun guru bahasa Indonesia penting untuk diteliti. Dengan demikian, tujuan dari penelitian ini adalah mengetahui (1) kesalahan ejaan dalam karangan eksplanasi karya siswa; (2) kesalahan struktur dalam karangan eksplanasi karya siswa; (3) faktor penyebab terjadinya kesalahan tersebut; (4) tindakan preventif siswa, guru dan pihak sekolah untuk mencegah kesalahan yang sama; dan (5) solusi yang diharapkan oleh siswa, guru dan pihak sekolah terkait tersebut.

\section{METODE}

Lokasi penelitian ini di SMP Negeri 1 Banyudono, Kabupaten

\section{HASIL DAN PEMBAHASAN}

\section{Ragam Kesalahan Penggunaan}

\section{Ejaan Bahasa Indonesia}

Berdasarkan analisis kesalahan penggunaan ejaan bahasa Indonesia

\section{Tabel 1. Persentase Kesalahan}

\section{Ejaan}

\begin{tabular}{|c|c|c|}
\hline Jenis Kesalahan & Banyak & Persentase \\
\hline Pemakaian Huruf & 325 & $72,70 \%$ \\
\hline 1. Huruf Kapital & 316 & $70,69 \%$ \\
\hline 2. $\quad$ Huruf Miring & 9 & $2,01 \%$ \\
\hline Penulisan Kata & 37 & $8,27 \%$ \\
\hline 1. $\quad$ Kata Dasar & 1 & $0,22 \%$ \\
\hline 2. Kata Berimbuhan & 18 & $4,03 \%$ \\
\hline Bentuk Ulang & 3 & $0,67 \%$ \\
\hline Gabungan Kata & 5 & $1,12 \%$ \\
\hline Pemenggalan Kata & 1 & $0,22 \%$ \\
\hline 6. Kata Depan & 7 & $1,57 \%$ \\
\hline 7. Singkatan dan Akronim & 1 & $0,22 \%$ \\
\hline 8. Kata Ganti & 1 & $0,22 \%$ \\
\hline Pemakaian Tanda Baca & 82 & $18,34 \%$ \\
\hline 1. Tanda Titik (.) & 29 & $6,50 \%$ \\
\hline 2. Tanda Koma (,) & 44 & $9,84 \%$ \\
\hline 3. $\quad$ Tanda hubung (-) & 6 & $1,34 \%$ \\
\hline 4. $\quad$ Tanda seru (!) & 1 & $0,22 \%$ \\
\hline 5. Tanda garis miring $(/)$ & 1 & $0,22 \%$ \\
\hline 6. Tanda titik koma $(;)$ & 1 & $0,22 \%$ \\
\hline Penulisan Unsur Serapan & 3 & $0,67 \%$ \\
\hline Total Kesalahan penggunaan ejaan & 447 & $99,98 \%$ \\
\hline
\end{tabular}

BASASTRA Jurnal Bahasa, Sastra, dan Pengajarannya

Volume 8 Nomor 2, Oktober 2020, P-ISSN 2302-6405, E-ISSN 2714-9765 
Rumus menghitung kesalahan pemakaian ejaan bahasa Indonesia tiap bidang kesalahan:

$$
\text { Persentase kesalahan }=\frac{\text { Jumlah kesalahan per bidang }}{\text { Total kesalahan ejaan }} \times 100 \%
$$

\begin{abstract}
Berdasarkan Tabel 1. dapat disimpulkan bahwa kesalahan penggunaan ejaan bahasa Indonesia pada keseluruhan sampel karangan ekaplanasi karya siswa kelas VIII berjumlah 447 kesalahan, meliputi kesalahan pada ragam penggunaan huruf, penulisan kata, pemakaian tanda baca, dan penulisan unsur serapan. Secara keseluruhan, kesalahan ejaan didominasi oleh kesalahan pemakaian huruf kapital berjumlah 316 kesalalahan atau $70,69 \%$ dari total kesalahan ejaan.
\end{abstract} Hal ini selaras penelitian Safitri, Setyawati \& Rifai (2020) bahwa sebanyak 43,75\% dari keseluruhan temuan kesalahan ejaan merupakan kesalahan huruf kapital.

Banyaknya temuan kesalahan berpengaruh terhadap penulisan dalam teks eksplanasi. Ada kalanya penulisan kata atau kalimat di dalam bahasa Indonesia menjadi salah akibat kesalahan penerapan fungsi huruf kapital (Sitorus, 2019). Kesalahan tersebut berkaitan dengan penulisan huruf kapital yang sering terjadi pada huruf-huruf tertentu, misalnya huruf "S", "K", dan "P", serta adanya kecenderungan siswa menggunakan huruf kapital di awal kata yang bukan berada pada awal kalimat. Adanya pola kesalahan tersebut menunjukkan bahwa siswa kurang memahami kaidah-kaidah penggunaan huruf kapital dengan benar.

\section{Ragam Kesalahan Struktur}

Ditemukan sebanyak 7 teks yang memiliki kesalahan struktur berdasarkan analisis yang telah dilakukan terhadap 21 karangan eksplanasi karya siswa kelas VIII SMP Negeri 1 Banyudono. Deskripsi mengenai bentuk kesalahan struktur karangan disesuaikan dengan temuan hasil analisis sebagai berikut:

\section{Struktur Karangan Tidak Runtut}

Struktur teks eksplanasi diawali dengan bagian pen-dahuluan, sebab-akibat, kemudian interpretasi. Namun, pada kutipan "Jika dianalisis lebih jauh lagi, Budaya Indonesia yang beragam tersebut sebenarnya banyak bertentangan dari etika atau norma sosial bahkan norma agama." (paragraf 1) menunjukkan bahwa bagian tersebut bukan me-rupakan pendahuluan, melainkan bagian sebabakibat.

Bagian pendahuluan justru termuat dalam kutipan "Bau nyale artinya menangkap nyale. nyale Ialah hewan laut di mana sejenis cacing laut yang bisa dikonsumsi." (paragraf 2) 
yang menjelaskan mengenai bau nyale dan nyale. Bagian tersebut merupakan bagian pernyataan umum untuk memberi gambaran pada pembaca tentang topik yang akan dibahas. Hal ini menunjukkan bahwa struktur karangan tersebut tidak runtut.

\section{Struktur Karangan Tidak Lengkap}

Bagian teks eksplanasi boleh untuk tidak dicantumkan adalah bagian interpretasi. Rahman (2018) menjelaskan bahwa bagian sebabakibat relatif menjawab pertanyaan 'bagaimana' dengan pernyataan, sedangkan bagian interpretasi merupakan pendapat singkat penulis tentang peristiwa yang dijelaskan sehingga boleh ada atau tidak ada dalam sebuah teks eksplanasi. Pada kutipan "Menurut kamus MerriamWebster, Cyberbullying berarti bentuk ancaman/ larangan yang dilakukan seseorang terhadap orang lain yang di sampaikan melalui pesan elektronik media." (paragraf 1) dan "Cyberbuliying merupakan Fenomena baru dari per-kembangan teknologi komunikasi pada kondisi sbg sebuah perbuatan menyakitil mengolok-olok yang di lakukan secara terus menerus dan sengaja melalui media komputer, telepon seluler/ apapun" (paragraf 2) merupakan bagian pendahuluan.

Namun, paragraf 3 pada kutipan "Perbuatan tersebut harus dihindari dan dikurangi oleh remaja dan tidak dilaksanakan hal-hal diatas" tidak memuat bagian sebab-akibat, melainkan bagian interpretasi yang berisi pendapat penulis. $\mathrm{Hal}$ ini menunjukkan bahwa teks tersebut memuat bagian pendahuluan dan interpretasi saja. Dengan demikian, tidak ditemukan adanya penjelasan mengenai mengapa atau bagaimana peristiwa cyberbulliying terjadi menunjukkan bahwa karangan tersebut tidak memiliki struktur yang lengkap.

\section{Jenis Karangan yang Rancu}

Karangan eksplanasi merupakan karangan yang menuntut adanya fakta terkait suatu peristiwa. Teks eksplanasi dibuat berdasarkan kejadian nyata dan fakta dengan mengumpulkan ber-bagai data dari berbagai sumber bukan berdasarkan daya imajinasi penulisnya (Nurdiana, Meisawati \& Mudikawaty, 2018). Pada kutipan "Sampah adalah suatu benda yang telah tidak dimanfaatkan lagi. keberadaan sampah Sangat menganggu kesehatan masyarakat yang berada disekitarnya." (kalimat 1 paragraf 1) hingga "Sampah termasuk diantara fenomena yang sering kali kita jumpai disekitar lingkungan masyarakat. Sampah dapat menimbulkan dampak yang dirasakan. Misalnya tanah longsor, Banjir, dan menjadi Sumber penyakit." (paragraf 2) merupakan bagian pendahuluan.

Namun, pada kutipan "Apabila kita memiliki kebiasaan membuang sampah secara sembarangan kedepannya akan banyak sekali dampak yang ditimbulkan." (paragraf 3) tidak memuat akibat apa yang ditimbul-kan dari sebab tersebut. Di sisi lain, kutipan "Ayolah bersamasama menjaga lingkungan di sekitar 
kita." (paragraf 4) justru memuat ajakan atau paragarf persuasi. Paragraf persuasi me-rupakan bagian karangan yang di-sampaikan menggunakan bahasa yang singkat, padat, dan menarik guna memengaruhi pembaca (Nugraheni, 2019).

Hasil analisis menunjukkan bahwa jenis teks tersebut menjadi rancu karena tidak memuat bagian sebab-akibat, tetapi justru memuat paragraf persuasi. Hal ini selaras dengan temuan Susilo \& Kholifah (2017) bahwa siswa kurang memahami tahapan fenomena dan kurang mampu mengembangkan teks eksplanasi sesuai struktunya. Padahal, teks eksplanasi memiliki fungsi sosial untuk memberikan penjelasan tentang proses terjadinya sesuatu peristiwa menggunakan prinsip sebab-akibat kepada masyarakat (Rahman, 2018). Hal ini menyebabkan teks tersebut tidak memenuhi fungsi sebagai teks eskplanasi. Dengan demikian, hal ini menunjukkan bahwa struktur karangan tidak lengkap juga memengaruhi kesalahan berupa jenis karangan menjadi rancu sehingga jenis kesalahan tersebut menjadi ragam kesalahan struktur yang dominan dalam karangan eksplanasi yang ditemukan.

\section{Faktor Penyebab Kesalahan Penggunaan Ejaan dan Struktur Karangan Eksplanasi}

Faktor pemicu adanya kesalahan penggunaan ejaan dan struktur karangan eksplanasi merupakan faktor-faktor yang kompleks, yaitu:

\section{Kurang latihan menulis}

Praktik lebih efektif untuk mempelajari ilmu terapan dibandingkan menghafalkan teorinya saja. Menulis merupakan kegiatan yang dapat dikuasai dengan praktik dan latihan secara berkesinambungan (Maelasari, Sunaendar, Sastromiharjo, \& Mulyati ,2019). Bahkan Ibda (2020) menyatakan bahwa keterampilan menulis dapat disebut sebagai ke-terampilan yang paling sulit bagi pelajar. Hal ini mengakibatkan siswa kurang berminat berlatih menulis seperti penemuan Hartidini, Syahrul \& Ratna (2018) yang menyatakan bahwa umumnya siswa kurang berminat untuk menulis karena kurangnya latih-an menulis karangan secara mandiri.

Berdasarkan hasil wawancara dengan narasumber, siswa banyak melakukan kesalahan penggunaan ejaan dan sebagian tidak menulis karangan eksplanasi sesuai strukturnya karena kurang latihan menulis. Hal ini sesuai dengan temuan Putri \& Syahrul (2019) dalam penelitian terkait teks laporan hasil observasi bahwa siswa kesulitan menuangkan fakta dalam bentuk tulisan serta belum menggunakan kebahasaan yang baik dan benar karena, dalam tugas latihan menulis yang diberikan, siswa hanya menuangkan ide pokok saja. Temuan tersebut menunjukkan bahwa siswa yang kurang berlatih menulis akan kesulitan menuangkan gagasannya dalam bentuk tulisan menggunakan bahasa yang baik dan benar, salah satunya terkait ejaan. 


\section{Kurang Teliti dalam Menulis}

Kurang teliti dalam menulis menjadi faktor penyebab terjadinya kesalahan penggunaan ejaan dan struktur karangan eksplanasi karya siswa kelas VIII C dan VIII G SMP Negeri 1 Banyudono yang disampaikan siswa dan guru pada saat wawancara. Hal ini didukung dengan temuan Septiana, Sumarwati \& Suyitno, (2015) dalam penelitiannya bahwa siswa kurang cermat dan kurang teliti dalam menulis sehingga banyak melakukan kesalahan penggunaan ejaan karena beranggapan bahwa yang terpenting adalah isi karangannya. Pemahaman siswa tentang penggunaan ejaan akan berpengaruh terhadap karangan yang dihasilkan karena siswa dapat dikatakan menulis karangan dengan baik apabila dapat menerapkan kaidah penggunaan ejaan pada karangan dengan benar (Rini \& Sahari, 2018). Selain itu, penuangan gagasan dalam bentuk tertulis menjadi kegiatan terencana yang memerlukan kecermatan dalam mewujudkan gagasan, menuliskan ejaan, bentukan kalimat yang baik, serta pemilihan kata yang tepat (Tugiati \& Kuntoro, 2019). Oleh karena itu, penting untuk menjaga fokus siswa saat menulis agar lebih teliti dan dapat menurunkan tingkat kesalahan penggunaan ejaan dan struktur yang dilakukan oleh siswa.
Kurangnya Pemahaman Siswa

Terkait Kaidah Ejaan dan Struktur Teks Eksplanasi

Siswa banyak melakukan kesalahan struktur karena kurang paham terhadap struktur teks eksplanasi, begitu juga dengan kesalahan ejaan. Hal ini terlihat dari hasil wawancara yang menunjukkan bahwa siswa belum memahami struktur teks eksplanasi dengan baik. Selain itu, kurangnya pemahaman ejaan dapat dilihat dari kesalahan penggunaan ejaan yang dilakukan siswa dalam karangan ekplanasi karya siswa. Rini \& Sahari (2018) dalam temuannya menyatakan bahwa siswa yang kurang paham peng-gunaan ejaan menempati urutan teratas sebesar $64,44 \%$ dan hanya 1 dari 36 siswa yang menempati kategori sangat paham penggunaan ejaan dengan presentase sebanyak 2,77\%. Hal ini menunjukkan bahwa kurangnya pemahaman siswa terkait kaidah ejaan dan struktur teks eksplanasi menyebab-kan siswa banyak melakukan kesalah-an dalam penggunaan ejaan dan struktur karangan eksplanasi.

\section{Kurangnya Minat Siswa dalam Mengikuti Pelajaran}

Hasil wawancara menunjukkan bahwa minat siswa dalam mengikuti pelajaran cenderung rendah karena pembelajaran yang membosankan bagi siswa. Terdapat hubungan sebabakibat dalam pembelajaran sehingga tindakan guru merupakan penyebab utama atas tindakan peserta didik selama pem-belajaran, meskipun tidak 
setiap tindakan peserta didik merupakan akibat dari tindakan guru mengajar (Rahmat, 2019). Penelitian Simamora, Harapan \& Kesumawati (2020) menemukan bahwa jika minat belajar $\left(\mathrm{X}_{2}\right)$ meningkat 1 unit skor maka prestasi belajar (Y) akan meningkat 0,519 unit skor, dengan ketentuan nilai minat belajar $\left(\mathrm{X}_{2}\right)$ konstan. Oleh karena itu, tidak mengherankan apabila materi yang disampaikan guru kurang dipahami siswa karena minat siswa untuk mengikuti pelajaran dan memperhatikan materi yang disampaikan oleh guru rendah karena bosan dengan proses mengajar yang guru terapkan.

\section{Kebiasaan Berbahasa Siswa.}

Hasil analisis maupun hasil wawancara dengan narasumber, salah satunya terkait penggunaan kata con= yang merupakan akibat dari penggunaan singkatan yang tidak tepat pada mata pelajaran yang lain. Hal ini selaras dengan hasil penelitian Sari (2018) bahwa dalam proses belajar mengajar hendaknya guru menerapkan bahasa formal karena hal tersebut berpengaruh terhadap perkembangan bahasa anak bahkan selalui diingat oleh mereka. Dengan demikian, penting adanya kesadaran setiap tenaga pendidik untuk menjaga penggunaan bahasa Indonesia yang baik dan benar selama proses belajar mengajar berlangsung pada setiap mata pelajaran dan pada setiap jenjang pendidikan karena sejatinya belajar bahasa merupakan sebuah proses yang berkesinambungan.

\section{Tindakan Preventif yang Telah Dilakukan untuk Mencegah Kesalahan Penggunaan Ejaan dan Struktur Karangan Eksplanasi}

\section{Tindakan Preventif oleh Siswa}

Belajar Menggunakan Ejaan dengan Benar dan Menulis Teks Eksplanasi

Siswa memilih belajar sebagai tindakan preventif yang mereka lakukan, yakni dengan cara menghafal dan berlatih. Belajar dengan hafalan hasilnya memang tampak dalam bentuk kemampuan mengingat pelajaran tersebut, tetapi kurang bisa diterapkan atau dikembangkan menjadi suatu pemikiran baru (Hakim, 2000). Hal ini dapat dilihat pada temuan mengenai kesalahan struktur teks. Septiana, Sumarwati \& Suyitno, (2015) dalam penelitiannya menemukan bahwa siswa kurang latihan menulis dan kurang men-dapat contoh dari pengajar sehingga siswa dapat mencari referensi sendiri tanpa tahu apakah referensi tersebut benar atau salah. Oleh karena itu, latihan menulis juga memerlukan pengawasan guru agar menjadi salah satu cara belajar yang tepat terhadap keterampilan menulis, dan tidak menyesatkan siswa karena mendapat contoh yang keliru.

\section{Tindakan Preventif oleh Guru}

Melakukan Koreksi Secara Langsung dan Menekankan Punishment

Berdasarkan wawancara dengan guru bahasa untuk kelas VIII di SMP Negeri 1 Banyudono menunjukkan bahwa guru telah 
melakukan tindakan koreksi langsung dan menekankan punishment kepada siswa sebagai bentuk tindakan preventif atas kesalahan penggunaan ejaan dan struktur teks eksplanasi karangan siswa. Guru memberikan corrective feedback tidak langsung yang ditindaklanjuti dengan revisi karangan oleh siswa. Punishment pengurangan nilai juga dilakukan terhadap karangan siswa yang memiliki banyak kesalahan dan kesalahan tersebut dilakukan secara berulang atau terhadap karangan yang telah direvisi oleh siswa dan tetap ditemukan kesalahan yang sama pada karya tersebut. Hal ini didukung dengan hasil penelitian Alwi (2019) yang menunjukkan bahwa terdapat pengaruh positif atas punishment yang diberikan terhadap motivasi Muhadatsah Yaumiyyah siswa berdasarkan nilai signifkansi $0,000<$ 0,05 dan nilai t hitung 5,416 > t tabel 1,968. Oleh karena itu, adanya punishment tersebut diharapkan dapat me-motivasi siswa untuk meningkatkan konsentrasi pada saat menulis karangan yang akan berimbas pada penurunan kesalahan penggunaan ejaan dan struktur karangan.

Menekankan Penggunaan Pedoman Ejaan (PUEBI) dan Ciri Khas Teks

Berdasarkan wawancara yang telah dilakukan dengan guru bahasa Indonesia SMP Negeri 1 Banyudono, menekankan penting-nya PUEBI dan ciri utama teks merupakan langkah preventif guru terkait kesalahan ejaan dan struktur teks, termasuk pada teks eksplanasi. Hal ini selaras dengan penelitian Rahman, Handayani, Ningrum \& Hudaya (2019) bahwa penggunaan PUEBI menjadi hal yang tidak lazim diucapkan bahkan diabaikan terutama oleh remaja pada pelaksanaan Industri 4.0 yang jika berlangsung secara berkesinambungan dapat mengakibat-kan pergeseran penggunaan PUEBI hingga penutur PUEBI dianggap tidak umum. Oleh karena itu, penting bagi guru untuk tidak hanya mengingatkan siswa agar mengakses PUEBI, tetapi juga memastikan bahwa siswa me-mahami konsep dalam PUEBI dan dapat menerapkannya dalam keseharian.

\section{Tindakan Preventif oleh Kepala Sekolah}

Melakukan Supervisi

Kegiatan supervisi oleh kepala sekolah merupakan salah satu upaya untuk melakukan pemantauan terhadap kinerja guru dan keberlangsungan pembelajar-an. Kepala sekolah akan mem-berikan masukan kepada guru terkait kinerja dan proses pem-belajaran yang dilaksanakan sehingga diharapkan memperoleh feedback berupa perubahan dan perbaikan oleh guru. Adanya perubahan cara mengajar dapat dilihat melalui peningkatan kemampuan mengajar sehingga kebiasaan lama yang kurang efektif dapat segera terdeteksi dan dihilangkan (Octavia, 2019). Marsilah (2018) dalam penelitian-nya menemukan bahwa pelaksana-an pengawasan yang semakin sering 
dilakukan, maka hal tersebut akan mendapat respon yang positif berupa kinerja guru menjadi optimal dan disiplin guru meningkat. Oleh karena itu, adanya supervisi yang rutin dapat me-ningkatkan kualitas pembelajaran, baik dari segi guru maupun siswa yang menciptakan kualitas pem-belajaran yang lebih baik.

\section{Menggiatkan Literasi Sekolah}

Membaca dan menulis merupakan dua keterampilan yang saling berkaitan erat. Seseorang dengan minat baca yang rendah akan kesulitan dalam menyajikan ide atau gagasan ke dalam bentuk tulisan karena kekurangan informasi dan kosakata yang terbatas (Sari \& Zulfikarni, 2020). Azimah \& Kurniawan (2019) dalam penelitiannya menyatakan bahwa literasi dalam pembelajaran bertujuan untuk menumbuhkan minat baca peserta didik guna meningkatkan kecapakan literasi menggunakan buku pengayaan atau buku teks pembelajaran. Oleh karena itu, penting untuk mendorong siswa membaca buku-buku yang memiliki kualitas peng-gunaan ejaan yang baik dan benar agar siswa mendapat contoh dan terbiasa dengan ejaan yang baik dan benar pula.
Solusi yang Diharapkan untuk Mengatasi Kesalahan Pemakaian Ejaan dan Struktur Karangan Eksplanasi

Menggunakan Media Pembelajaran yang Menyenangkan dan Padat Materi

Media pembelajaran diperlukan guna menunjang proses pembelajaran agar lebih mudah dipahami siswa. Indartiwi, Wulandari \& Novela (2020) dalam penelitiannya menjelaskan bahwa media pembelajaran menjadi penting bagi proses pembelajaran materi yang memiliki tingkat kesukaran tinggi untuk dipahami bagi siswa. Hal ini dikarenakan penggunaan media yang tepat dapat mempermudah guru dalam menyampaikan materi serta membuat siswa aktif berpartisipasi dalam proses pembelajaran (Divan, dkk., 2020).

Hasil wawancara menunjukkan adanya keinginan siswa atas media pembelajaran yang menyenangkan sehingga dapat memicu siswa untuk bersemangat mengikuti pembelajaran. Pendapat Trimantara (dalam Hartidini, Syahrul \& Ratna, 2018) bahwa salah satu faktor penyebab pem-belajaran menulis tidak mencapai hasil yang diharapkan adalah ketiadaan atau keterbatasan media pembelajaran menulis yang efektif. Salah satu faktor penyebab rendah-nya partisipasi siswa dalam pembelajaran membuat karangan adalah terbatasnya media pembelajaran yang menarik bagi siswa (Maelasari, Sunaendar, Sastromiharjo \& Mulyati, 2019). Penjelasan tersebut 
membuktikan bahwa penting untuk mewujudkan media yang menarik karena memicu semangat siswa untuk fokus pada materi yang disampai-kan. Oleh karena itu, guru perlu menyesuaikan media seperti apa yang dibutuhkan dan diinginkan siswa guna mengikuti pem-belajaran dengan efektif dan menyenangkan.

\section{Mewujudkan Suasana Pembelajaran yang Menyenangkan}

Hasil wawancara menunjukkan bahwa kecenderungan merasa bosan mengikuti pembelajaran menyebabkan siswa mengantuk dan tidak fokus pada materi yang disampaikan guru. Hartidini, Syahrul \& Ratna (2018) dalam penelitiannya menemukan bahwa strategi pembelajaran yang kurang bervariasi dalam pem-belajaran menulis karangan argumentasi merupakan salah satu penyebab siswa tidak berminat mengikuti pelajaran bahkan cenderung merasa bosan. Di sisi lain, guru bermaksud memberikan motivasi melalui cerita yang menginspirasi dan menjadikan cerita sebagai strategi untuk menarik perhatian siswa mengikuti pem-belajaran. Guru harus mampu "menghidupkan" kelasnya dengan proses pembelajaran yang tidak membuat siswa jenuh dan mampu menjadikan guru sebagai idola siswa, kreatif dan inspiratif (Salman, 2018). Namun, cerita yang disampaikan guru justru menyebabkan suasana pembelajaran menjadi membosankan bagi siswa. Proses pembelajaran yang terasa kering dapat menyebabkan siswa tidak bersemangat bahkan kehilangan motivasi untuk mengikuti kegiatan belajar mengajar (Suardi \& Marwan, 2019). Dengan demikian, menciptakan suasana pendidikan yang bermakna, menyenangkan, kreatif, dinamis, dan dialogis merupakan salah satu kewajiban guru sebagai tenaga pengajar (Octavia, 2019). Oleh karena itu, guru harus mampu memilah mana cerita yang perlu disampaikan dan bagaimana cara menjadikan pembelajarannya menyenangkan agar siswa ter-motivasi untuk mengikuti pem-belajaran dengan nyaman.

Solusi yang Diharapkan Guru untuk Mengatasi Kesalahan Pemakaian Ejaan dan Struktur Karangan Eksplanasi

Membiasakan Penggunaan PUEBI Kepada Siswa

Hasil wawancara terhadap guru bahasa Indonesia menunjuk-kan bahwa guru mewajibkan setiap siswa untuk memiliki, mengunduh, atau mengakses PUEBI baik secara daring maupun luring. Muzaki, Chadis \& Agustin (2019) dalam penelitiannya menyatakan bahwa pengenalan PUEBI dirasa sangat penting karena dalam kegiatan pembelajaran masih minim menggunakan bahasa Indonesia yang baik dan benar.

Pemahaman siswa terkait PUEBI masih rendah dibuktikan dengan fakta bahwa sebagaian siswa menjawab tidak mengetahui mengenai PUEBI pada saat wawancara. Pemahaman siswa tentang penggunaan 
ejaan akan berpengaruh terhadap karangan yang dihasilkan karena siswa dapat dikatakan menulis karangan dengan baik apabila dapat menerapkan kaidah penggunaan ejaan pada karangan dengan benar (Rini \& Sahari, 2018). Oleh karena itu, pembiasaan penggunaan PUEBI pada saat pembelajaran penting untuk dilakukan agar dapat memastikan setiap siswa benar-benar telah menggunakan PUEBI sebagai pedoman penggunaan ejaan bahasa Indonesia pada karangan yang dibuat.

\section{Adanya Sinergi Antarguru Mata Pelajaran}

Bahasa merupakan keterampilan yang dipelajari se-panjang hayat. Oleh karena itu, proses belajar mengenai ke-terampilan berbahasa sudah dimulai sejak jenjang sekolah dasar dan terus berlangsung, bahkan saat siswa mengikuti mata pelajaran selain Bahasa Indonesia seperti yang disampaikan narasumber guru bahasa Indonesia SMP Negeri 1 Banyudono saat wawancara. Selain sebagai kebiasaan, aktivitas bahasa merupakan bagian dari sebuah keterampilan yang harus dipelajari, dipertahankan, ditingkatkan untuk mencapai tujuan pembelajaran dan mencari pengetahuan (Ibda, 2020). Selain itu, bahasa Indonesia sebagai bahasa pengantar dunia pendidikan juga merupakan mata pelajaran wajib diajarkan di sekolah (Muzaki, Chadis \& Agustin, 2019). Oleh karena itu, setiap guru harus sadar bahwa penggunaan bahasa Indonesia pada saat mata pelajaran lain juga memengaruhi kemampuan ber-bahasa siswa. Wicaksono \& Siska (2020) menemukan bahwa peng-integrasian keterampilan membaca dengan keterampilan menulis dapat meningkatkan pembelajaran siswa disemua disiplin ilmu karena mengharuskan siswa untuk lebih aktif terlibat dalam hal yang di-pelajarinya. Oleh karena itu, sinergi antara guru semua mata pelajaran dalam meningkatkan ke-terampilan berbahasa siswa dapat menunjang pemahaman siswa tidak hanya pada bidang bahasa, tetapi pada keseluruhan ilmu pengetahu-an yang dipelajari siswa.

\section{Solusi yang Diharapkan Kepala} Sekolah untuk Mengatasi Kesalahan Pemakaian Ejaan dan Struktur Karangan Eksplanasi

Meningkatkan Kerja Sama Siswa dan Guru dalam Mencapai Tujuan Pembelajaran

Kerja sama sangat diperlu-kan dalam upaya mencapai tujuan pembelajaran. Hal ini disampaikan Widayati (2019) dalam penelitian-nya bahwa posisi guru dan siswa boleh berbeda, tetapi keduanya tetap seiring dan setujuan dalam mencapai tujuan bersama. Semakin komunikatif dan interaktif komunikasi yang dibangun antara guru dan siswa dalam pembelajaran, semakin memungkinkan tercapainya tujuan pembelajaran secara optimal (Suardi \& Marwan, 2019). Interaksi dalam bentuk dominasi guru sebagai pendorong di 
dalam kelas dan kerja sama yang ditandai dengan kepedulian ter-hadap kebutuhan dan pendapat orang lain sebagai sebuah tim merupakan kekuatan sentral dalam hubungan guru-murid yang efektif (Suwanto, 2020). Kerja sama dan interaksi yang harmonis antara siswa dan guru dapat menciprakan suasana pembelajaran yang menyenangkan dan memicu pembelajaran tersebut yang nyaman.

\section{Adanya Sinergi Antarlembaga}

Keberhasilan dalam pendidikan tidak hanya ditentukan oleh kemampuan guru dalam mengajar. Hal ini didukung hasil wawancara dengan kepala sekolah SMP Negeri 1 Banyudono bahwa adanya sinergi antarlembaga sangat diperlukan guna menunjang pen-didikan yang berkualitas, termasuk dalam upaya pengajaran bahasa. Hal ini selaras dengan penelitian Sunarti (2020) bahwa bahwa sekolah akan mengalami kesulitan mengakomondasikan berbagai tuntutan tanpa dukungan pihak-pihak di luar sekolah yang akan memengaruhi kualitas layanan pendidikan di sekolah. Oleh karena itu, adanya kolaborasi berupa peninjauan oleh lembaga terkait dengan pelaksanaan pembelajaran di sekolah penting diterapkan agar kebijakan yang dibuat sesuai dengan kondisi riil di sekolah dan masalah yang ada selama proses pembelajaran dapat segera ditangani dengan kebijakan-kebijakan yang tepat.

\section{SIMPULAN}

Berdasarkan hasil analisis dan pembahasan mengenai kesalahan peng-gunaan ejaan dan struktur karangan eksplanasi karya siswa kelas VIII SMP Negeri 1 Banyudono tahun pelajaran 2019/2020 dapat disimpulkan sebagai berikut. Pertama, terdapat empat ragam kesalahan penggunaan ejaan dalam karangan eksplanasi tersebut, yaitu kesalahan penulisan unsur serapan $(0,06 \%)$, kesalahan penulisan kata $(8,27 \%)$, kesalahan pemakaian tanda baca $(18,34 \%)$, dan kesalahan pemakaian huruf $(72,70 \%)$ yang didominasi oleh kesalahan huruf kapital (70,69\%) berupa adanya pola kesalahan penulisan huruf yang berada di awal kata dan penulisan huruf tertentu sebagai huruf kapital.

Kedua, ragam kesalahan struktur karangan eksplanasi karya siswa kelas VIII SMP Negeri 1 Banyudono meliputi struktur karangan tidak runtut, jenis karangan yang rancu, dan struktur karang-an tidak lengkap menjadi kesalahan paling berpengaruh tersebut karena tanpa bagian sebab-akibat dapat memicu kerancuan jenis teks yang ada.

Ketiga, faktor penyebab adanya kesalahan ejaan dan struktur tersebut adalah kurang latihan menulis, kurang teliti dalam menulis, kurangnya pemaham-an siswa terkait kaidah ejaan dan struktur teks eksplanasi, kebiasaan berbahasa siswa, serta kurangnya minat siswa dalam mengikuti pelajaran yang merupakan faktor yang mendominasi sebagai 
penyebab banyaknya kesalahan penggunaan ejaan dan struktur karangan eksplanasi.

Keempat, tindakan preventif guna mencegah terjadinya kesalahan peng-gunaan ejaan bahasa Indonesia dan struktur karangan tersebut oleh siswa berupa belajar menggunakan ejaan dengan benar dan menulis teks eksplanasi, guru memilih melakukan koreksi secara langsung dan menekankan punishment serta menekankan penggunaan pedoman ejaan (PUEBI) dan ciri khas teks kepada siswa, dan pihak sekolah, terutama kepala sekolah, melakukan supervisi dan meng-giatkan literasi sekolah.

Kelima, solusi yang diharapkan untuk mengatasi kesalahan penggunaan ejaan dan struktur karangan eksplanasi, yakni siswa memberikan saran untuk menggunakan media pembelajaran yang menyenangkan dan padat materi, serta mewujudkan suasana pembelajaran yang menyenangkan; saran dari guru ialah membiasakan penggunaan PUEBI kepada siswa dan adanya sinergi antarguru mata pelajaran; dan saran dari kepala sekolah ialah meningkatkan kerja sama siswa dan guru dalam mencapai tujuan pembelajaran, serta adanya sinergi antarlembaga dalam mengatasi permasalahan terkait hal tersebut.

\section{REFERENSI}

Alwi, S. (2019). Pengaruh Reward dan Punishment Terhadap Motivasi Siswa dalam Muhadatsah
Yaumiyyah di Pondok Pesantren Modern Tgk. Chiek Oemar Diyan Aceh Besar. Lisanuna, 9(1), 60-77.

Azimah, R. \& Kurniawan, O. (2019). Implementasi Gerakan Literasi Sekolah dalam Pembelajaran di Kelas Tinggi. Jurnal PAJAR: Pendidikan dan Pengajaran, 3(4), 934-947.

Divan,S., Baci, R., Nardi, M., Wejang, H.E.A., Sam, A., \& Rofita, D. (2020). Peningkatan Kreativitas Guru dalam Mendesain Kartu Menjadi Media Pembelajaran di Sekolah Dasar. Randang Tana: Jurnal Pengabdian Masyarakat, $3(2), 85-92$.

Hakim, Thursan. (2000). Belajar Secara Efektif. Jakarta: Puspa Swara

Hartidini, S., R. Syahrul, \& Ratna, E. (2018). Pengaruh Strategi Pembelajaran Inkuiri Berbantuan Media Audiovisual Terhadap Keterampilan Menulis Karangan Argumentasi Siswa Kelas X SMA Negeri 2 Lengayang Kabupaten Pesisir Selatan. Jurnal Pendidikan Bahasa dan Sastra Indonesia, 1(7), 63-69.

Ibda, H. (2020). Peningkatan Keterampilan Menulis Resensi Buku Ilmiah pada Mahasiwa Melalui Program Satu Semester Satu Resensi (Tuter Tensi). Disastra: Jurnal Pendidikan Bahasa dan Sastra Indonesia, 2(1), 1-13.

Ibda, H. (2020). Bahasa Indonesia Tingkat Lanjut untuk Mahasiswa: Dilengkapi 
Caturtunggal Keterampilan Berbahasa. Semarang: CV. Pilar Nusantara

Indartiwi, A., Wulandari, J. \& Novela,

T. (2020). Peran Media Interaktif dalam Pembelajaran di era Revolusi Industri 4.0. 28-31. Prosiding Konferensi Pendidikan Nasional "Strategi dan Implementasi Pendidikan Karakter pada Era Revolusi Industi 4.0". Yogyakarta: FKIP Universitas Mercu Buana Yogyakarta.

Maelasari, N., Sunaendar, D., Sastromiharjo, A., \& Mulyati, Y. (2019). Model Pembelajaran Mind Mapping Berbasis NilaiNilai Profetik Bagi Peningkatan Kemampuan Menulis Eksposisi Siswa Kelas X SMAN 1 Baleendah Bandung. Prosiding Seminar Internasional Riksa Bahasa XIII. 1405-1414. Bandung: Sekolah Pascasarjana Universitas Pendidikan Indonesia.

Markhamah \& Sabardila, A. (2014). Analisis Kesalahan dan Karakteristik Bentuk Pasif. Surakarta: Muhammadiyah University Press.

Marsilah, S. (2018). Pengaruh Pengawasan Kepala Sekolah Terhadap Disiplin Guru dalam Mengajar pada SDN Kayuringin Jaya III Bekasi Selatan Semester Genap Tahun Pelajaran 2016/2017. Pedagogik, 6(1), 3140.
Muzaki, A., Chadis \& Agustin, Y. (2019). Pengenalan Pedoman Umum Ejaan Bahasa Indonesia (PUEBI) dalam Mengembangkan Kemampuan Berbahasa Indonesia yang Baik dan Benar Bagi Para Guru. Jurnal PKM: Pengabdian kepada Masyarakat. 2(2), 82-86.

Nasrillah, E., Kosasih, E. \& Kurniawan, K. (2019). Teks Eksplanasi Sebagai Bahan Ajar Bahasa Indonesia di Kelas XI SMAN 5 Bandung: Kajian Deskriptif Kualitatif terhadap Fungsi, Struktur, dan Kaidah Kebahasaan dalam Proses Pembelajaran Berbasis Genre. Diaglosa, 3(1), 68-73.

Nugraheni, A.S. (2019). Bahasa Indonesia di Perguruan Tinggi Berbasis Pembelajaran Aktif. Jakarta: Prenadamedia Group.

Nurdiana, A., Meisawati, M., \& Mudikawaty,M. (2018). Super Complete SD/MI 4,5,6. Depok: Magenta Media.

Nurdjan, S., Firman \& Mirnawati. (2018). Bahasa Indonesia untuk Perguruan Tinggi. Makassar: Penerbit Aksara Timur.

Octavia, S. A. (2019). Sikap dan Kinerja Guru Profesional. Yogyakarta: Penerbit Deepublish.

Putri, D. \& Elvina. (2019). Keterampilan Berbahasa di Sekolah Dasar: Melalui Metode Game's. Pasuruan: CV Penerbit Qiara Media. 
Putri, D., \& Syahrul, R. (2019). Korelasi Keterampilan Membaca Pemahaman dan Keterampilan Menulis Teks Laporan Hasil Observasi Siswa Kelas VII SMP Negeri 4 Pariaman. Jurnal Pendidikan dan Sastra Indonesia. 8(1), 62-69.

Rahman, T. (2018). Teks dalam Kajian Struktur dan Kebahasaan. Semarang: CV. Pilar Nusantara. Rahman, A.A., Handayani, S.R., Ningrum, D. \& Hudaya, A.P. (2019). Impromptu Speech untuk Kesejahteraan Psikologis Penggunaan PUEBI yang Lebih Baik. Prosiding Seminar Internasional Riksa Bahasa XIII. Bandung: Sekolah Pascasarjana Universitas Pendidikan Indonesia, 145-154.

Rahmat (2019). Evaluasi Pembelajaran Pendidikan Agama Islam. Yogyakarta: Bening Pustaka.

Rini, P.W. \& Sahari, S. (2018. Pemahaman Penggunaan Ejaan terhadap Kemampuan Menulis Karangan Siswa Sekolah Dasar. ibriez: Jurnal Kependidikan Dasar Berbasis Sains, 3(2), 8186

Sari, D.P. \& Zulfikarni (2020). Korelasi

Keterampilan

Membaca

Pemahaman dengan

Keterampilan Menulis Teks Eksposisi SIswa Kelas X SMA Negeri 3 Padang. Jurnal Pendidikan Bahasa dan Sastra Indonesia, 9(1), 39-49.

Sari, W.M. (2018). Penggunaan Bahasa

Pengantar Guru dalam
Pengembangan Kemampuan Berbahasa Anak Didik di SD Negeri $\quad 84 \quad$ Kota Bengkulu.Repository IAIN Bengkulu.

Safitri, D.H., Setyawati, N. \& Rifai, A. (2019). Analisis Kesalahan Ejaan pada Surat Dinas Peserta Didik Kelas VII SMP NU 06 Kedungsuren Kaliwungu Selatan Kendal Tahun Pelajaran 2018/2019. Dwijaloka, 1 (1), 3237.

Salman, M.S. (2018). Menjadi Guru yang Dicintai Siswa. Yogyakarta: Deepublish

Septiana, N.A., Sumarwati, \& Suyitno (2015). Analisis Kesalahan Struktur Teks dan Pemakaian Bahasa Indonesia pada Teks Biografi Karya Siswa SMP. Basastra: Jurnal Penelitian Bahasa, Sastra Indonesia dan Pengajarannya, 3(3), 1-13.

Simamora, T., Harapan, E., \& Kesumawati, N. (2020). FaktorFaktor Determinan yang Mempengaruhi Prestasi Belajar Siswa. JMKSP: Jurnal Manajemen, Kepemimpinan, dan Supervisi Pendidikan, 5(2) 191201.

Sitorus, J.P. (2019). Mengenal Tata Bahasa Indonesia. Malang: CV. Evernity Fisher Media.

Suardi, M. \& Marwan (2019). Strategi Pembelajaran. Yogyakarta: Penerbit Parama Ilmu.

Sunarti (2020). Partisipasi Masyarakat dalam Pengembangan Manajemen Pendidikan di 
SMPN 4 Banjarmasin. Jurnal

Terapung: Ilmu-Ilmu Sosial, 2 (1), 27-38.

Susilo, J. \& Kholifah, U. (2017).

Pembelajaran Memproduksi

Teks Eksplanasi Kompleks

Menggunakan Pembelajaran

Berbasis Proyek untuk Siswa

SMK. DEIKSIS: Jurnal

Pendidikan Bahasa dan Sastra

Indonesia, 11 (1), 76-92.

Suwanto, M.A. (2020). Transformasi Sekolah: Transformasi Menjadi Sekolah Masa Depan.

Tugiati, T. \& Kuntoro (2019).

Penggunaan Ejaan Bahasa

Indonesia Sesuai PUEBI untuk

Kepentingan Penulisan

Perangkat Pembelajaran.

Seminar Nasional Hasil

Penelitian dan Pengabdian pada

Masyarakat IV "Pengembangan

Sumberdaya menuju Masyarakat

Madani Berkearifan Lokal".

325-327. Purwokerto: LPPM

Universitas Muhammadiyah

Purwokerto.

Wicaksono, A., \& Siska, Y. (2020).

Literacy Collaborative Models:

Mengatasi Masalah Membaca-

Menulis Permulaan pada Siswa

Sekolah Dasar. 391-408.

Prosiding Seminar Nasional

2020 "Transformasi Pendidikan

Dasar di Era Disrupsi dalam

Pengembangan Karakter".

Bandar Lampung: STKIP PGRI

Bandar Lampung.

Widayati, S. (2019). Peran Guru dalam

Pembelajaran Bahasa. Jurnal
Elsa: Edukasi Lingua Sastra, 7(1), 1-14. 